\title{
Postdigital Perspectives on the McPolicy of Measuring Excellence
}

\author{
Sarah Hayes ${ }^{1}$
}

Accepted: 23 November 2020 / Published online: 19 December 2020

(C) Springer Nature Switzerland AG 2020

\section{University Policy as Static Structure or Dynamic Infrastructure}

Something that struck me early on during the first Covid-19 lockdown (as it did many people) was the empty roads that ceased to be occupied. Looking upwards on local walks, I contemplated a sky free of planes, and I reflected on an infrastructure taken for granted, as the way many (but not all of us) live, work and construct our leisure activities (Jandrić et al. 2020). Weeks into the lockdown, I noticed my work bags still in the same spot (yes, I'm that tidy), barely touched since they were dropped there, save to remove my laptop and phone. Given that 'an infrastructure is defined by use and movement' (Berlant 2016: 393), you could argue that my workbag and its contents, my car, myself, the motorways I use to reach campus, and lifts I get into once I arrive, are all interconnected infrastructure. These and other linked elements are all in use, and their movement helps to constitute my academic activities.

Higher education (HE) is full of movement and use (as the articles in this Special Issue richly illustrate). There are though some more static systems and structures in HE that seem not to connect with the dynamic flow of cultural models and knowledge that constitutes a university and its interconnectivity with all aspects of social, scientific and technological activities. Berlant (2016: 393) argues that 'infrastructure is not identical to system or structure'. I wonder then in universities how much some of our policies, as static texts not in dynamic and active use, remain grounded in the structure, but fail to travel to effect change across the infrastructure.

Though ceasing to travel during the pandemic had benefits, I instantly missed it. In the months since then, I have reflected that a walk through an airport would now be a novel experience. More recently, I smiled too at this headline: 'Why People Pay Hundreds of Dollars to Eat on Grounded Planes' (Davies 2020). At the same time as judging them for being sad acts who need to get a life, I was intrigued by their reasoning. I also found myself defensive of their freedom to choose (what to me may

Sarah Hayes

sarah.hayes@wlv.ac.uk

1 University of Wolverhampton, Wolverhampton, UK 
seem) a 'reduced' experience in our McDonaldised society (Ritzer 1993, 2018; Ritzer et al. 2018) when our familiar infrastructure has been ruptured by the Covid-19 virus.

In McDonaldised HE, a curious structure has come to be adopted in recent years as if it were 'normal'. In a widespread discourse that I have referred to as McPolicy (Hayes 2019b), it is assumed that it is possible to 'measure the excellence' of something universities can 'deliver' called 'the student experience'. This rational policy language reflects the forms of efficiency, calculability, predictability and control that Ritzer $(1993,2018)$ described, but has led also to an irrationality, as linguistically, the active academic labour of human beings seems to be missing from the discourse (Hayes 2019b). Well before Covid-19, HE was already experiencing a form of 'linguistic lockdown' enacted via McPolicy that attempts to measure excellence via institutional data, not people. A key problem this raises is that whilst the significance of data grows, the experience of insignificance felt by humans can also intensify (Leone 2020). Narrow calculative structures can restrict what is knowable and thinkable in complex patterns of human interaction. Once a 'glitch' such as Covid-19 occurs, these structures become visible for what they always were: not a reflection of infrastructure, just one form of structural organisation. As such, HE requires new 'thinking infrastructures' that really reflect the living mediation of what organises life and learning to help us redo and rework restrictive policy models (Kornberger et al. 2019).

The university, as a key site of knowledge production and consumption, had thus been 'distancing' its students and staff through policy discourse way before Covid-19 entered the scene. Yet as HE moved rapidly online, it was never more apparent that students were craving human contact with their professors alongside online interaction (Arundel 2020). Unfortunately, HE has begun to resemble a rather more expensive version of the grounded planes offer, while students (isolating in their rooms) argue they have been 'scammed' by communications that are still promising them an 'amazing experience' (Arundel 2020). HE of course is not the airline industry. Yet the sector has travelled so far now in a direction of embedding its McUniversity role (Hayes 2017) as a journey of McExcellence, that in becoming grounded by a pandemic, this structure struggles to retain significance to people, not dissimilar to a stationary plane, failing to take off.

When this Special Issue was conceived, it was connected to the Higher Education Institutional Research (HEIR) Conference ${ }^{1}$ at University of Wolverhampton, UK, in September 2019. This event took place in the Lord Swraj Paul Building, which sits alongside the famous Molineux Football Stadium in central Wolverhampton. Only 6 months later, as articles for this issue began to flow in, the pandemic altered our entire environment. It became 'anthropologically strange' to us (Dingwall et al. 2013), as we were required to distance ourselves from the infrastructure we had come to accept. Such fundamental change indicates though that our 'social arrangements can, and must, change when biological environments change' (Dingwall et al. 2013). Whatever 'new normal' emerges, it will be more appropriate to our needs if it is also recognised as interlinked with rapid social, political, economic, technological and biological changes in postdigital society (Jandrić et al. 2018).

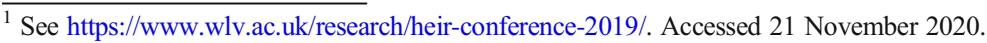




\section{The Challenges of 'Measuring Excellence' in Dynamic Infrastructures}

In this issue, authors explore the concept of 'measuring excellence' and the dilemmas it raises in the postdigital context now surrounding universities, including the complexities thrown into the mix by Covid-19. For Dennis Hayes (2019a), a keynote speaker at HEIR 2019, unquestioning compliance with this concept ignores a responsibility that academics have 'to refuse to be told what to think'. As such, we each have a duty towards academic freedom that overrides any 'rationality of governance', where efficiency is measured via data in an 'audit culture' (Shore and Wright 1999), and a 'therapy' and 'victim' culture has also emerged (Ecclestone and Hayes 2019). Of course, we have been measuring a great deal in HE, including research as well as teaching excellence, and even as I write, UK institutions are finalising submissions to the Research Excellence Framework (REF). ${ }^{2}$

Another keynote speaker at HEIR 2019, and also the Editor-in-Chief of Postdigital Science and Education, argues that REF brings only one 'particular concept of research excellence into being' (Jandrić 2020a). This can overlook dialectical relationships with the processes of academic publishing, as a form of 'social production' that takes place across the economy, politics and culture, all of which are in turn accommodating both old and new technology in our postdigital age (Jandrić and Hayes 2019: 381). In such a context, 'measuring inclusion, participation and opportunity are ever more problematic and challenged' for Traxler (2020). He argues that even if there had been progress before Covid-19, movement, fluidity, change and now massive instability are ever more pervasive and ubiquitous. As such, 'our capacity to understand, let alone measure, these and their relationship to equity and education will be poorly understood for years to come' (Traxler 2020). In his second commentary for this volume, Jandrić (2020b) questions the frequently opaque and contentious practice of peer review of articles when academic publishing is central to knowledge development. After a review of key issues related to political economy and the epistemology of academic publishing, he outlines 'a new postdigital knowledge ecology' in Postdigital Science and Education that could be 'of interest to scholars in diverse fields and disciplines'.

Other articles in this issue attest to the enormous diversity of HE activity that any approach for measuring excellence encounters. Welch (2020) argues against a subordination of human values to market values in $\mathrm{HE}$, where 'claims made for excellence are hollow when the achievements of institutions come at the expense of the well-being of students and staff'. She calls instead for collective campaigns that provide student opportunities and contribute to local economies. Suggesting a more ecological approach towards teaching evaluation over a 'datafication of quality', Fawns et al. (2020) emphasise the ongoing aspects of adaptive, collaborative integration of design and practice. They point to a need to include those aspects of teaching and learning that do not show up in digital data, as well as their relationship to those that do. Ralston (2020) picks up on HE's 'microcredentialing craze' to offer a postdigital Deweyan critique. As the 'value of a university degree plummets, the popularity of the digital microcredential has soared' to provide 'a panacea for skills gaps, workforce stagnation, and automationinduced labour market shocks'. He suggests a more deliberative, constructive approach to microcredentialing as an alternative to the current craze.

\footnotetext{
$\overline{2}$ See https://www.ref.ac.uk. Accessed 21 November 2020.
} 
Partington (2020) argues that developing inclusive pedagogies requires a clearer understanding that students really are in fact 'learner consumers'. She contends that 'the purpose of HE is not to compensate for an assumed unequal distribution of competences' but to 'recognize what all students bring to their learning' and to 'value the unexpected ways in which they might do this'. Royle (2020) describes the introduction of a range of learning modalities into HE settings in Jordan and Palestine using problem-based learning and actor network theory as instruments of design for educational change. Lecture capture policies and the challenges these present for universities are examined by Ibrahim et al. (2020). Then Warnes (2020) considers what impact teaching fellowships awarded to HE staff really makes. He found that Fellows did not change practice after receiving an award, perceiving that they were 'already excellent', managers showed little interest and students were mainly unaware of excellent teaching awards.

In the field of health, Aitken (2020) advocates a more 'holistic evaluation of educational quality'. This, she suggests, 'necessitates considering novel and theorized measures of quality as well as more instrumental metrics' that look at the particular needs of the student group. Then in the field of languages, West (2020) undertook a conversation analytic study of managing advice and resistance and supporting autonomy in undergraduate supervision. In the postdigital university, 'do we need just a little of that human touch?', ask Cureton et al. (2020), in relation to supporting students to feel they really belong in HE. Finally, Hayes et al. (2020) present the case for raising regional academic voices through provocative debate, when these can otherwise become silenced by data-driven measures of excellence that dominate policy.

\section{Postdigital Thinking Infrastructures Require Policy that Can Travel}

Across all of these articles a questioning of the McPolicy of measuring excellence is critiqued through a postdigital lens which helps to illuminate the organic movement and nature of $\mathrm{HE}$ infrastructure and the individual positionality (not rationality) of postdigital experiences (Hayes forthcoming 2021). Our universities are currently grounded by the pandemic, and this 'glitch' is proving to be far reaching in the way that it has disrupted our familiar infrastructure. We can of course attempt to reboard a McPolicy approach and seek a new normal that resembles what we had before the pandemic. Rather like those booking an experience on a grounded plane, we can seek to replicate our former structure. It is worth taking a closer look though, at the varied reasoning behind even the decisions of people to eat on a stationery plane.

It turned out that the economy class price wasn't all that bad, given that people experienced an A380 with food, drinks, inflight entertainment (and even extra legroom with the social distancing requirement). Others might argue 'you can do all of this at home with Netflix and a takeaway meal' (Davies 2020), just as you can study your university course entirely online. Different customers wanted to support the national airline in its financial struggle, and some just wanted an Instagram moment from their splurge. Finally, there were those who were simply afraid to take off. This way they could have the dining experience and even an expensive suite on a plane, but never leave the ground. McDonaldised experiences like this are structured to be efficient, predictable, calculable and controlled. 
This may be sufficient for those seeking a McPlane experience but replicating the McPolicy of measuring excellence in postpandemic HE just leaves universities grounded at the airport of McExcellence. This is because McPolicy measures only static structures like 'the student experience' but fails to adapt to and integrate with the dynamic infrastructures that authors describe in this Special Issue. Rather than remain in a safe structural loop of measuring only what seems easy to control on the ground, other routes are there to be explored to effect change. This requires new postdigital 'thinking infrastructures' for policy that can adapt though to the living mediation of what now organises life. McPolicy may keep us grounded, but HE needs to take off.

\section{References}

Aitken, G. (2020). A postdigital exploration of online postgraduate learning in healthcare Professionals: A Horizontal Conception. Postdigital Science and Education. https://doi.org/10.1007/s42438-020-00103-w.

Arundel, S. (2020). My last bit of in person teaching was cancelled and now I've had enough. Quite frankly, I feel like I've been scammed. The Leeds Tab, 13 November. https://hetab.com/uk/leeds/2020/11/13/mylast-bit-of-in-person-teaching-was-cancelled-and-now-ive-had-enough-52931. Accessed 20 Nov 2020.

Berlant, L. (2016). The commons: infrastructures for troubling times. Environment and Planning D: Society and Space, 34(3), 393-419. https://doi.org/10.1177/0263775816645989.

Cureton, D., Jones, J., \& Hughes, J. (2020). The postdigital university: do we still need just a little of that human touch? Postdigital Science and Education. https://oi.org/10.1007/s42438-020-00204-6.

Davies (2020). Why people pay hundreds of dollars to eat on grounded planes, Bloomberg, 16 October. https://www.bloomberg.com/news/articles/2020-10-16/why-people-pay-hundreds-of-dollars-to-eat-on-agrounded-plane. Accessed 20 Nov 2020.

Dingwall, R., Hoffman, L. M., \& Staniland, K. (2013). Introduction: why a sociology of pandemics? Sociology of Health \& Illness, 35(2), 167-173. https://doi.org/10.1111/1467-9566.12019.

Ecclestone, K., \& Hayes, D. (2019). The dangerous rise of therapeutic education. London and New York: Routledge.

Fawns, T., Aitken, G., \& Jones, D. (2020). Ecological teaching evaluation vs the datafication of quality: understanding education with, and around, data. Postdigital Science and Education. https://doi.org/10. 1007/s42438-020-00109-4.

Hayes, D. (2017). Beyond McDonaldization: visions of higher education. Abingdon: Taylor and Francis.

Hayes, D. (2019a). How the university lost its way: sixteen threats to academic freedom. Postdigital Science and Education. https://doi.org/10.1007/s42438-019-00079-2.

Hayes, S. (2019b). The labour of words in higher education: is it time to reoccupy policy? Leiden: Brill.

Hayes, S. (forthcoming 2021). Postdigital positionality: developing powerful, inclusive narratives for learning, teaching, research and policy in higher education. Leiden: Brill.

Hayes, S., Jopling, M., Hayes, D., Westwood, A., Tuckett, A., \& Barnett, R. (2020). Raising regional academic voices (alongside data) in higher education (HE) debate. Postdigital Science and Education. https://doi.org/10.1007/s42438-020-00131-6.

Ibrahim, Y., Howarth, A., \& Stone, I. (2020). Lecture capture policies: a survey of British universities. Postdigital Science and Education. https://doi.org/10.1007/s42438-020-00102-x.

Jandrić, P. (2020a). Postdigital research measurement. Postdigital Science and Education. https://doi.org/10. 1007/s42438-020-00105-8.

Jandrić, P. (2020b). A peer-reviewed scholarly article. Postdigital Science and Education. https://doi.org/10. 1007/s42438-020-00202-8.

Jandrić, P., \& Hayes, S. (2019). The postdigital challenge of redefining education from the margins. Learning, Media and Technology, 44(3), 381-393. https://doi.org/10.1080/17439884.2019.1585874.

Jandrić, P., Jaldemark, J., Hurley, Z., Bartram, B., Matthews, A., Jopling, M., Mañero, J., MacKenzie, A., Irwin, J., Rothmüller, N., Green, B., Ralston, S. J., Pyyhtinen, O., Hayes, S., Wright, J., Peters, M. A., \& Tesar, M. (2020). Philosophy of education in a new key: who remembers Greta Thunberg? Education and environment after the coronavirus. Educational Philosophy and Theory. https://doi.org/10.1080/ 00131857.2020.1811678. 
Jandrić, P., Knox, J., Besley, T., Ryberg, T., Suoranta, J., \& Hayes, S. (2018). Postdigital science and education. Educational Philosophy and Theory, 50(10), 893-899. https://doi.org/10.1080/00131857. 2018.1454000.

Kornberger, M., Bowker, G. C., Elyachar, J., Mennicken, A., Miller, P., Nucho, J. R., \& Pollock, N. (Eds.). (2019). Thinking infrastructures. Bingley: Emerald Group Publishing.

Leone, M. (2020). On insignificance: the loss of meaning in the post-material age. London and New York: Routledge.

Partington, A. (2020). Developing inclusive pedagogies in HE through an understanding of the LearnerConsumer: Promiscuity, Hybridisation, and Innovation. Postdigital Science and Education. https://doi. org/10.1007/s42438-020-00110-x.

Ralston, S. J. (2020). Higher Education's microcredentialing craze: a postdigital-Deweyan critique. Postdigital Science and Education. https://doi.org/10.1007/s42438-020-00121-8.

Ritzer, G. (1993). The McDonaldisation of society. Thousand Oaks: Pine Forge Press.

Ritzer, G. (2018). The McDonaldisation of society: into the digital age (9th ed.). Thousand Oaks: Sage Publications.

Ritzer, G., Jandrić, P., \& Hayes, S. (2018). Prosumer capitalism and its machines. Open Review of Educational Research, 5(1), 113-129. https://doi.org/10.1080/23265507.2018.1546124.

Royle, K. (2020). What's good what's bad? conceptualising teaching and learning methods as technologies using actor network theory in the context of Palestinian higher education. Postdigital Science and Education. https://doi.org/10.1007/s42438-020-00138-z.

Shore, C., \& Wright, S. (1999). Audit culture and anthropology: neo-liberalism in British higher education. Journal of the Royal Anthropological Institute, 5(4), 557-575.

Traxler, J. (2020). Inclusion, measurement and relevance... and Covid-19. Postdigital Science and Education. https://doi.org/10.1007/s42438-020-00182-9.

Warnes, M. (2020). Questioning the impact of teaching fellowships on excellent teachers. Postdigital Science and Education. https://oi.org/10.1007/s42438-020-00107-6.

Welch, P. (2020). Mass higher education in England - a success story? Postdigital Science and Education. https://doi.org/10.1007/s42438-020-00111-w.

West, M. (2020). 'I'm not going to tell you Cos you need to think about this': a conversation analysis study of managing advice resistance and supporting autonomy in undergraduate supervision. Postdigital Science and Education. https://doi.org/10.1007/s42438-020-00194-5. 